\title{
Transition Metal Complexes of Ethopropazine: Synthesis and Characterization
}

\author{
V. Debbeti ${ }^{1}$, T. J. Ahmad ${ }^{1}$, S. Ananda ${ }^{2}$, N. M. Made Gowda ${ }^{1, *}$ \\ ${ }^{1}$ Department of Chemistry, Western Illinois University, One University Circle, Macomb, 61455, USA \\ ${ }^{2}$ Department of Studies in Chemistry, University of Mysore, Manasagangothri, Mysore, 570 006, India
}

\begin{abstract}
Ethopropazine (EP) or profenamine is a phenothiazine derivative, $\mathrm{N}^{10}$-(2-diethylaminopropyl)phenothiazine (Figure.1), used as an antiparkinsonian drug that has anticholinergic, antihistamine, and antiadrenergic actions. Transition metal complexes of $\mathrm{ZnBr}_{2}, \mathrm{CdBr}_{2}, \mathrm{CdI}_{2}$, and $\mathrm{HgBr}_{2}$ have been synthesized using $\mathrm{EP}$ as the main ligand and purified by recrystallization in $\mathrm{MeOH}$. These products have been characterized based on their elemental analysis, molar conductance, magnetic susceptibility, IR and ${ }^{1} \mathrm{H}-\mathrm{NMR}$ data. The molecular formulations of the new mononuclear complexes have been found to be $\left[\mathrm{Zn}\left(\mathrm{C}_{19} \mathrm{H}_{24} \mathrm{~N}_{2} \mathrm{~S} . \mathrm{HCl}\right)_{2}\right] \mathrm{Br}_{2},\left[\mathrm{Cd}\left(\mathrm{C}_{19} \mathrm{H}_{24} \mathrm{~N}_{2} \mathrm{~S} . \mathrm{HCl}\right)_{2}\right] \mathrm{Br}_{2},\left[\mathrm{Cd}\left(\mathrm{C}_{19} \mathrm{H}_{24} \mathrm{~N}_{2} \mathrm{~S} . \mathrm{HCl}\right)_{2}\right] \mathrm{I}_{2} \quad$ and $\left[\mathrm{Hg}\left(\mathrm{C}_{19} \mathrm{H}_{24} \mathrm{~N}_{2} \mathrm{~S} . \mathrm{HCl}\right)\right.$ $\left.\left(\mathrm{C}_{19} \mathrm{H}_{24} \mathrm{~N}_{2} \mathrm{~S} . \mathrm{HBr}\right)\left(\mathrm{OH}_{2}\right)\right] \mathrm{Br}_{2}$, where the ligand, $\mathrm{EP}=\mathrm{C}_{19} \mathrm{H}_{24} \mathrm{~N}_{2} \mathrm{~S}$. All the complexes show an ionic ratio of 1:2 in acetonitrile solutions. Molecular structures have been proposed. The four-coordinate complex cations of $\left[\mathrm{Zn}_{(}\left(\mathrm{C}_{19} \mathrm{H}_{24} \mathrm{~N}_{2} \mathrm{~S} . \mathrm{HCl}\right)_{2}\right]$ $\mathrm{Br}_{2},\left[\mathrm{Cd}\left(\mathrm{C}_{19} \mathrm{H}_{24} \mathrm{~N}_{2} \mathrm{~S} . \mathrm{HCl}\right)_{2}\right] \mathrm{Br}_{2}$, and $\left[\mathrm{Cd}\left(\mathrm{C}_{19} \mathrm{H}_{24} \mathrm{~N}_{2} \mathrm{~S} . \mathrm{HCl}\right)_{2}\right] \mathrm{I}_{2}$ contain an sp ${ }^{3}$ hybridized metal(II) center each with a tetrahedral environment. On the other hand, six-coordinate cationic species of $\left[\mathrm{Hg}\left(\mathrm{C}_{19} \mathrm{H}_{24} \mathrm{~N}_{2} \mathrm{~S} . \mathrm{HCl}\right)\left(\mathrm{C}_{19} \mathrm{H}_{24} \mathrm{~N}_{2} \mathrm{~S} . \mathrm{HBr}\right)\left(\mathrm{OH}_{2}\right)\right] \mathrm{Br}_{2}$ complex with an $\mathrm{sp}^{3} \mathrm{~d}^{2}$ hybridized metal center exhibits the octahedral geometry.
\end{abstract}

Keywords Ethopropazine Hydrochloride, Transition Metal Complexes, Synthesis, Characterization, Analysis

\section{Introduction}

The study of metal-N-alkylphenothiazine complexes has been growing into a research field having special interest both in preparative and biological activities[1]. $\mathrm{N}$-alkylphenothiazines (NPTZs) are biologically active heterocyclic compounds. Ethopropazine or profenamine (parsidol, parsidan or parkin), is a phenothiazine derivative, N-10-(2-diethylaminopropyl)phenothiazine (Figure.1), used as an antiparkinsonian agent that has anticholinergic, antihistamine, and antiadrenergic actions. Considering the fact that some platinum(II)-NPTZ complexes are used as antitumor agents[2], it is likely that other transition metal-NAPTZ complexes would behave as more potent and/or less toxic drugs than the free ligands themselves. Furthermore, a considerable increase in the fungicidal activity of some NPTZs due to their complexation with copper(II)[3,4] and uranium oxide[5] has been reported.

Previously, some studies of transition metal-NPTZ complexes have been reported by several workers[4-16]. Keshavan and co-workers[4-7] have synthesized and characterized compounds of selected NPTZs with molybdenum(IV), tungsten(IV), ruthenium(II/III) and copper(II). Keshavan and Janardhan[7] and Gowda and

* Corresponding author:

gn-made@wiu.edu (N. M. Made Gowda)

Published online at http://journal.sapub.org/chemistry

Copyright (C) 2012 Scientific \& Academic Publishing. All Rights Reserved
Jayarama[8] have reported mononuclear copper(II) and zinc(II) complexes of NPTZs. Kroener et al.[9] have studied the X-ray crystal structures of several cis- and trans-bis (2,2'-bipyridine)-bis (phenothiazine-S) ruthenium (II) hexaflurophosphates. Made Gowda et al. have previously studied the synthesis and characterization of coordination compounds of NPTZs with rhodium (II/III), rhenium (VII), iridium (III/IV), molybdenum (IV/V), zinc(II), palladium(II) and mercury(II)[10-16]. Chaitanya Lakshmi et al have reported transition metal-pyridoxine complexes[17-19]. In continuation of the project on the coordination chemistry of NPTZ com-plexe, the study of synthesis and characterization of transition metal complexes using EP. $\mathrm{HCl}$, as the main ligand, is reported.

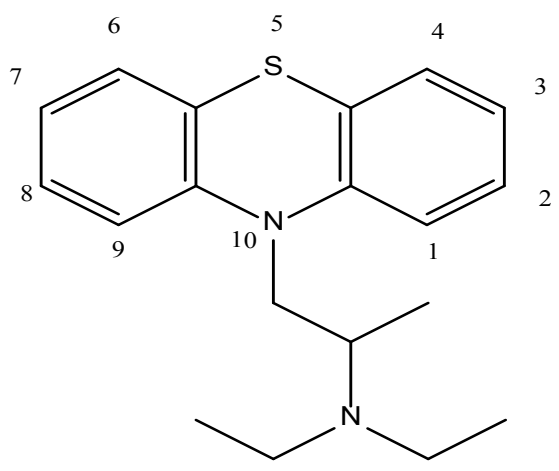

Figure. 1. Molecular structure of ethopropazine

\section{Experimental}




\subsection{Materials}

Metal salts, zinc bromide, cadmium bromide, cadmium iodide and mercuric bromide, and the ligand, ethopropazine hydrochloride (99\% purity) from Aldrich/Sigma Chemical Company were used as supplied.

All solvents such as methanol, ethanol, diethyl ether, dimethyl sulfoxide, dimethyl formamide and DMSO- $\mathrm{d}_{6}$ (Cambridge isotope laboratories Inc.) were of ACS reagent grade and were used without further purification. Double distilled water was used in all preparations.

\subsection{Physical Measurements}

Elemental analyses of the complexes were performed by the Microanalysis Laboratory, University of Illinois, Urbana-Champaign, IL. Molar conductance was determined with a Conductance-Resistance meter. UV-Visible spectra were recorded on a Shimadzu UV1601 spectrophotometer. The infrared spectra were recorded on a Shimadzu FTIR 8400 spectrometer using potassium bromide pellets. ${ }^{1} \mathrm{H}-\mathrm{NMR}$ spectra were recorded on a JEOL-300 $\mathrm{MHz}$ FT-NMR spectrometer in DMSO- $\mathrm{d}_{6}$. Mass magnetic susceptibilities of the complexes were measured at room temperature with a Johnson Matthey magnetic susceptibility balance which uses $\mathrm{HgCo}(\mathrm{SCN})_{4}$ as a calibrant.

\subsection{General Synthesis of Complexes}

A solution of the transition metal salt (x mmol) $\left(\mathrm{ZnBr}_{2}\right.$, $\mathrm{CdBr}_{2}, \mathrm{CdI}_{2}$ and $\mathrm{HgBr}_{2}$ ) dissolved in a minimum volume of $\mathrm{MeOH}$ was slowly added with stirring to a concentrated methanolic solution of EP.HCl (2x mmol) and refluxed overnight. Each reaction mixture was cooled overnight at $0^{\circ} \mathrm{C}$ and the precipitated product isolated by suction filtration through a medium-glass fritted funnel. The product was washed with small amounts of cold water first followed by methanol, air-dried, and dried in vacuo over anhydrous $\mathrm{CaSO}_{4}$ in a desiccator. Each crude product was recrystallized twice from its hot saturated solution in methanol. The yield was determined.

\section{Results and Discussion}

The elemental analysis data of the new metal-EP.HCl complexes listed in Table 1 show that the theoretical values are in agreement with the experimental ones. Physical properties of the complexes are presented in Table 2. All the complexes are colorless, except $\mathrm{ZnBr}_{2}(\mathrm{EP} . \mathrm{HCl})_{2}$, which is grayish. They are microcrystalline and stable at room temperature with percent yields ranging from 47 to 83 . They have a narrow range of melting points indicating their relative purity. The complexes are slightly soluble in common polar solvents such as $\mathrm{MeOH}$ and readily soluble in DMF and DMSO.

The stoichiometric reactions involved in the complex formation are represented by the equations (1) and (2) below.

$$
\mathrm{MX}_{2}+2 \mathrm{EP} \cdot \mathrm{HCl} \longrightarrow \mathrm{MX}_{2}(\mathrm{EP} . \mathrm{HCl})_{2}
$$

Where $\mathrm{M}=\mathrm{Zn}\left(\mathrm{II}_{)}\right.$or $\mathrm{Cd}(\mathrm{II})$ and $\mathrm{X}$ is $\mathrm{Br}$ or I,

$$
3 \mathrm{HgBr}_{2}+4 \mathrm{EP} . \mathrm{HCl} \longrightarrow 2 \mathrm{HgBr}_{2}(\mathrm{EP} . \mathrm{HCl})(\mathrm{EP} . \mathrm{HCl})
$$

In the reaction for the formation of $\mathrm{Hg}(\mathrm{II})$ complex (eq. (2)), the larger $\mathrm{Hg}(\mathrm{II})$ ion as a soft acid tends to preferentially coordinate with the soft base $\mathrm{Br}^{-}$as compared to the relatively harder $\mathrm{Cl}^{-}$ion of the ligand. The molecular formulations and structures of the complexes were determined on the basis of elemental analysis, molar conductance, UV-Vis, IR, and NMR data.

\begin{tabular}{|c|c|c|c|c|}
\hline $\begin{array}{l}\text { Complex, } \\
\text { molecular formula }\end{array}$ & $\begin{array}{c}\text { Ionic formula* } \\
(\mathrm{molar} \text { mass, } \mathrm{g} / \mathrm{mol})\end{array}$ & $\begin{array}{l}\% \mathrm{C}, \exp \\
\text { (calcd.) }\end{array}$ & $\begin{array}{l}\% \mathrm{H}, \text { exp } \\
\text { (calcd.) }\end{array}$ & $\begin{array}{l}\% \mathrm{~N}, \exp \\
\text { (calcd.) }\end{array}$ \\
\hline $\mathrm{ZnBr}_{2}(\mathrm{EP} . \mathrm{HCl})_{2}$ & $\begin{array}{c}{\left[\mathrm{Zn}\left(\mathrm{C}_{19} \mathrm{H}_{24} \mathrm{~N}_{2} \mathrm{~S} . \mathrm{HCl}\right)_{2}\right] \mathrm{Br}_{2}} \\
(923.07)\end{array}$ & $\begin{array}{c}49.97 \\
(49.44)\end{array}$ & $\begin{array}{c}5.62 \\
(5.46)\end{array}$ & $\begin{array}{c}6.18 \\
(6.07)\end{array}$ \\
\hline $\mathrm{CdBr}_{2}(\mathrm{EP} . \mathrm{HCl})_{2}$ & $\begin{array}{c}{\left[\mathrm{Cd}\left(\mathrm{C}_{19} \mathrm{H}_{24} \mathrm{~N}_{2} \mathrm{~S} . \mathrm{HCl}\right)_{2}\right] \mathrm{Br}_{2}} \\
(970.09)\end{array}$ & $\begin{array}{c}46.82 \\
(47.00)\end{array}$ & $\begin{array}{c}5.20 \\
(4.90)\end{array}$ & $\begin{array}{c}5.73 \\
(5.70)\end{array}$ \\
\hline $\mathrm{CdI}_{2}(\mathrm{EP} . \mathrm{HCl})_{2}$ & $\begin{array}{c}{\left[\mathrm{Cd}\left(\mathrm{C}_{19} \mathrm{H}_{24} \mathrm{~N}_{2} \mathrm{~S} . \mathrm{HCl}\right)_{2}\right] \mathrm{I}_{2}} \\
(1064.1)\end{array}$ & $\begin{array}{c}42.29 \\
(42.00)\end{array}$ & $\begin{array}{c}4.57 \\
(4.50)\end{array}$ & $\begin{array}{c}5.15 \\
(5.20)\end{array}$ \\
\hline $\mathrm{HgBr}_{2}(\mathrm{EPHCl})(\mathrm{EPHBr}) \cdot 2 \mathrm{H}_{2} \mathrm{O}$ & $\begin{array}{c}{\left[\mathrm{Hg}\left(\mathrm{C}_{19} \mathrm{H}_{24} \mathrm{~N}_{2} \mathrm{~S} . \mathrm{HCl}\right)\right.} \\
\left.\left(\mathrm{C}_{19} \mathrm{H}_{24} \mathrm{~N}_{2} \mathrm{~S} . \mathrm{HBr}\right)\left(\mathrm{OH}_{2}\right)\right] \mathrm{Br}_{2}(1058.3)\end{array}$ & $\begin{array}{c}40.30 \\
(40.07) \\
\end{array}$ & $\begin{array}{c}4.30 \\
(4.74)\end{array}$ & $\begin{array}{c}5.03 \\
(4.92) \\
\end{array}$ \\
\hline
\end{tabular}

Table 1. Elemental data of the metal-EP·HCl complexes

*Based on molar conductances shown in Table 2.

\begin{tabular}{|c|c|c|c|c|c|}
\hline Complex & Melting point $\left({ }^{\circ} \mathrm{C}\right)$ & $\begin{array}{c}\text { Molar conductance (mho } \mathrm{cm}^{2} \\
\left.\mathrm{~mol}^{-1}\right)^{*} \text { (ionic ratio) }\end{array}$ & $\begin{array}{c}\text { Mass magnetic } \\
\text { susceptibility }\left(10^{-6} \mathrm{cgs}\right)\end{array}$ & Color & $\begin{array}{c}\text { Yield } \\
(\%)\end{array}$ \\
\hline $\mathrm{ZnBr}_{2}(\mathrm{EP} . \mathrm{HCl})_{2}$ & $160-163$ & $\begin{array}{c}196 \\
(1: 2 \text { electrolyte })\end{array}$ & -0.705 & Lt. grayish & 82.9 \\
\hline $\mathrm{CdBr}_{2}(\mathrm{EP} . \mathrm{HCl})_{2}$ & $160-165$ & $\begin{array}{c}238 \\
\text { (1:2 electrolyte) } \\
\end{array}$ & -0.22 & colorless & 46.7 \\
\hline $\mathrm{CdI}_{2}(\mathrm{EP} \cdot \mathrm{HCl})_{2}$ & $142-145$ & $\begin{array}{c}228 \\
\text { (1:2 electrolyte) }\end{array}$ & -0.05 & colorless & 67.2 \\
\hline $\begin{array}{l}\mathrm{HgBr}_{2}(\mathrm{EPHCl}) \\
(\mathrm{EPHBr}) \cdot 2 \mathrm{H}_{2} \mathrm{O}\end{array}$ & $169-170$ & $\begin{array}{c}184 \\
\text { (1:2 electrolyte) }\end{array}$ & -0.60 & colorless & 62.4 \\
\hline
\end{tabular}

Table 2. Physical properties of the metal-EP $\cdot \mathrm{HCl}$ complexes

* $1.00 \mathrm{mM}$ complex solution in acetonitrile 
The molar conductances for the complexes, measured in acetonitrile solution, presented in Table 2 indicate that all complexes behave as 1:2 electrolytes. Mass magnetic susceptibilities $\left(\mathrm{X}_{\mathrm{g}}\right)$ for the complexes are in the range of $-0.05 \times 10^{-6}$ to $-0.705 \times 10^{-6}$ c.g.s at $23^{\circ} \mathrm{C}$ (Table.2). The magnetic data are consistent with the metal systems which are of low spin (diamagnetic) type due to the absence of unpaired electrons in the metal(II) d-subshell. The metal ions containing a common d-electron configuration of $\mathrm{d}^{10}$ exhibit diamagnetism, as expected.

The molecular formulations listed in Table 1 show that each complex contains a metal(II) center and two ethopropazine hydrohalide molecules as principal ligands.. Additionally, the complex of $\mathrm{HgBr}_{2}$ contains two $\mathrm{H}_{2} \mathrm{O}$ molecules as water of hydration.

The UV-Visible spectral data of the ligand (EP.HCl) and its complexes are presented in Table 3 . The broad bands observed in the region of $260-307 \mathrm{~nm}$ in the spectra of all complexes can be attributed to the intraligand transitions. The molar absorptivities of the complexes falling in the range of $4.58 \times 10^{4}$ to $5.49 \times 10^{4} \mathrm{~L} \mathrm{~mol}^{-1} \mathrm{~cm}^{-1}$, are higher than that of the ligand in the free state which is $1.74 \times 10^{4} \mathrm{~L} \mathrm{~mol}^{-1}$ $\mathrm{cm}^{-1}$. The shift in the bands in UV-Vis spectra are attributed to the intramolecular transitions of $\pi \rightarrow \pi^{*}$ type. This may be taken as an indirect evidence for the involvement of $\mathrm{N}$ atoms of EP in the coordination process. The electronic spectra confirm the complexation between metal ions and the EP.HX ligand[15-23].

Relevant IR absorption frequencies of the EP.HCl ligand and its metal complexes are presented in Table 4. In the uncomplexed $\mathrm{EPHCl}$, the presence of a broad band in the $2080-2700 \mathrm{~cm}^{-1}$ range is assigned to the interaction of the quaternary ammonium ion, $\left(\mathrm{R}_{3} \mathrm{NH}\right)^{+}$, with a halide ion[12-15,21,22]. In the IR spectra of the complexes, this band has shifted with diminished intensity suggesting that the exocyclic $\mathrm{N}$ atom of the alkylamino group is indirectly involved in coordination with the metal center. A band observed in the $3047-2870 \mathrm{~cm}^{-1}$ region in the spectrum of EP.HCl may be assigned to the heterocyclic nitrogen atom carrying an alkyl amine side chain[21,22]. This band of EP.HCl shows a shift upon complexation suggesting its coordination to the metal(II) center[10-14]. In addition, $\mathrm{HgBr}_{2}$ complex shows a broad band in the $3240-3600 \mathrm{~cm}^{-1}$ region, supporting the hydrogen bonded $\mathrm{OH}$ interactions of the water molecules. Additionally, the $\mathrm{Hg}$ (II) complex spectrum shows that bands in the $680-700 \mathrm{~cm}^{-1}$ region, attributable to the heterocyclic C-S-C modes, undergo a shift, suggesting the involvement of heterocyclic $\mathrm{S}$ atom as a coordination site[12,15,22]. The ${ }^{1} \mathrm{H}-\mathrm{NMR}$ data for the ligand, EP.HCl, and its complexes are presented in Figure. 2 and Table 5. Some general trends exist in the proton-NMR spectra of the EPHCl ligand and all its complexes. In the spectra of the uncomplexed EP.HCl and its complexes, the broad singlet due to the quarternary ammonium ion, $\left(\mathrm{R}_{3} \mathrm{NH}\right)^{+}$, of the free ligand, which occurs far downfield $(\delta 10.3)$, has shifted upfield in the spectra of all the complexes indicating the existence of $\mathrm{H}$-bonding between the exocyclic $\mathrm{N}$ atom and the halogen atom bonded to the metal(II) center $[12,15,24]$.

Crystals of sufficient quality required for x-ray crystallographic analysis of the complexes could not be grown. Based on the discussed analytical data, tentative structures have been proposed for the complexes based on several factors (Figure. 3.a-3.b). Similar structures have been reported for other transition metal complexes of phenothiazines and pyridoxine[12-15,17-19,24]. The ionic ratio from the molar conductance data is found to be $1: 2$ for all the complexes, thus supporting the formula as $\left[\mathrm{M}(\mathrm{EP} . \mathrm{HCl})_{2}\right]^{2+} 2 \mathrm{X}^{-}$for the $\mathrm{zinc}(\mathrm{II})$ and cadmium(II) complexes. The ionic formula for the $\mathrm{Hg}$ (II) complex is $\left[\mathrm{Hg}(\mathrm{EP} . \mathrm{HCl})(\mathrm{EP} . \mathrm{HBr})\left(\mathrm{OH}_{2}\right)_{2}\right]^{2+} 2 \mathrm{Br}^{-}$. The four-coordinate complex cations of the $\mathrm{Zn}(\mathrm{II})$ and $\mathrm{Cd}(\mathrm{II})$ complexes contain an $\mathrm{sp}^{3}$ hybridized metal(II) center with a tetrahedral environment (3.a). On the other hand, the six-coordinate cationic species of $\mathrm{Hg}(\mathrm{II})$ complex with an $\mathrm{sp}^{3} \mathrm{~d}^{2}$ hybridized metal center exhibits the octahedral geometry (3.b). The presence of hydrogen bond between the exocyclic $\mathrm{N}$ atom and the halogen atom bonded to the $\mathrm{M}(\mathrm{II})$ center is confirmed by the upfield shift of the broad singlet at 10.3 ppm in the $\mathrm{H}^{1}$-NMR spectra of the complexes. The $\left[\mathrm{Hg}(\mathrm{EPHCl})(\mathrm{EPHBr})\left(\mathrm{OH}_{2}\right)_{2}\right] \mathrm{Br}_{2}$ complex containing a $\mathrm{Br}^{-}$ion in place of original $\mathrm{Cl}^{-}$ion as part of the EP ligand can be justified based on the Pearson's HSAB interactions. Since $\mathrm{Hg}(\mathrm{II})$ is a soft acid, it prefers to coordinate with a soft base. The source of $\mathrm{Br}^{-}$ion is the reactant $\mathrm{HgBr}_{2}$ used in the reaction. The distorted octahedral geometry is supported by its diamagnetic behaviour evident from the magnetic susceptibility data (Table 2) $[14,15]$. Similar transition metal complex structures have been reported in the literature[10-15].

Table 3. UV-Visible spectral data of the metal-EP·HCl complexes

\begin{tabular}{|c|c|c|c|}
\hline Complex/Ligand & $\lambda_{\max }(\mathrm{nm})$ & Molar absorptivity $(\varepsilon)\left(10^{4}, \mathrm{~L} \mathrm{~mol}^{-1} \mathrm{~cm}^{-1}\right)$ & Transition \\
\hline EP.HCl & 260.5 & 1.74 & $\pi \rightarrow \pi^{*}$ \\
\hline $\mathrm{ZnBr}_{2}(\mathrm{EP} . \mathrm{HCl})_{2}$ & 262.5 & 4.58 & $\pi \rightarrow \pi^{*}$ \\
\hline $\mathrm{CdBr}_{2}(\mathrm{EP} . \mathrm{HCl})_{2}$ & 261.0 & 4.92 & $\pi \rightarrow \pi^{*}$ \\
\hline $\mathrm{CdI}_{2}(\mathrm{EP} . \mathrm{HCl})_{2}$ & 260.5 & 5.49 & $\pi \rightarrow \pi^{*}$ \\
\hline $\mathrm{HgBr}_{2}(\mathrm{EP} . \mathrm{HCl})(\mathrm{EP} . \mathrm{HBr}) .2 \mathrm{H}_{2} \mathrm{O}$ & 262.0 & 5.34 & $\pi \rightarrow \pi^{*}$ \\
\hline
\end{tabular}


Table 4. Important $\mathrm{IR}$ absorption bands of $\mathrm{EP} . \mathrm{HCl}$ and its metal complexes

\begin{tabular}{|c|c|c|c|c|}
\hline Complex/Ligand & Absorption of $\left(\mathrm{R}_{3} \mathrm{NH}^{+}\right)\left(\mathrm{cm}^{-1}\right)$ & Absorption of $\left(>\mathrm{N}-\mathrm{R}^{1}\right)\left(\mathrm{cm}^{-1}\right)$ & Absorption of $(\mathrm{C}-\mathrm{S}-\mathrm{C})\left(\mathrm{cm}^{-1}\right)$ & Absorption of $(\mathrm{OH})\left(\mathrm{cm}^{-1}\right)$ \\
\hline EP.HCl & $2700-2080$ & $3047-2870$ & $700-680$ & - \\
\hline $\mathrm{ZnBr}_{2}(\mathrm{EP} . \mathrm{HCl})_{2}$ & $2500-2100$ & $3088-2880$ & $700-680$ & - \\
\hline $\mathrm{CdBr}_{2}(\mathrm{EP} . \mathrm{HCl})_{2}$ & $2450-2200$ & $3055-2864$ & $700-680$ & - \\
\hline $\mathrm{CdI}_{2}(\mathrm{EP} . \mathrm{HCl})_{2}$ & $2560-2100$ & $3091-2872$ & $700-680$ & - \\
\hline $\begin{array}{c}\mathrm{HgBr} \\
\mathrm{PgP} . \mathrm{HCl})(\mathrm{E}\end{array}$ & $2550-2100$ & $3055-2868$ & $690-625$ & $3600-3240$ \\
\hline
\end{tabular}

Table 5. ${ }^{1} \mathrm{H}-\mathrm{NMR}$ data of $\mathrm{EP} . \mathrm{HCl}$ and its metal complexes*

\begin{tabular}{|c|c|}
\hline Ligand/Complex & Chemical shift (multiplicity, protons) (Fig. 2) \\
\hline EP.HCl & (a) $1.15-1.30(\mathrm{~m}, 9 \mathrm{H})$, (b) $3.05-3.20(\mathrm{~m}, 4 \mathrm{H})$, (c) $3.57(\mathrm{~m}, 1 \mathrm{H})$, (d) $4.15-4.55(\mathrm{~m}, 2 \mathrm{H}),(\mathrm{e}) 7.00-7.36(\mathrm{~m}, 8 \mathrm{H})$, (f) 10.30 (br.s,1H) \\
\hline $\mathrm{ZnBr}_{2}(\mathrm{EP} . \mathrm{HCl})_{2}$ & (a) $1.18-1.32(\mathrm{~m}, 9 \mathrm{H})$, (b) $3.15-3.38(\mathrm{~m}, 4 \mathrm{H})$, (c) $3.57(\mathrm{~m}, 1 \mathrm{H}),(\mathrm{d}) 4.16-4.43(\mathrm{~m}, 2 \mathrm{H}),(\mathrm{e}) 7.00-7.29(\mathrm{~m}, 8 \mathrm{H}),(\mathrm{f}) \underline{9.19}$ (br.s,1H) \\
\hline $\mathrm{CdBr}_{2}(\mathrm{EP} . \mathrm{HCl})_{2}$ & (a) $1.18-1.30(\mathrm{~m}, 9 \mathrm{H})$, (b) $3.15-3.33(\mathrm{~m}, 4 \mathrm{H})$, (c) $3.57(\mathrm{~m}, 1 \mathrm{H}),(\mathrm{d}) 4.16-4.4(\mathrm{~m}, 2 \mathrm{H}),(\mathrm{e}) 7.00-7.29(\mathrm{~m}, 8 \mathrm{H})$, (f) 9.11 (br.s, $1 \mathrm{H})$ \\
\hline $\mathrm{CdI}_{2}(\mathrm{EP} . \mathrm{HCl})_{2}$ & (a) $1.17-1.30(\mathrm{~m}, 9 \mathrm{H})$, (b) $3.17-3.38(\mathrm{~m}, 4 \mathrm{H})$, (c) $3.57(\mathrm{~m}, 1 \mathrm{H})$ (d) 4.16-4.37 (m, 2H), (e) 7.00-7.29 (m, 8H), (f) 8.91 (br.s,1H) \\
\hline $\begin{array}{c}\mathrm{HgBr}_{2}(\mathrm{EP} \cdot \mathrm{HCl})( \\
\text { EP.HBr }) \cdot 2 \mathrm{H}_{2} \mathrm{O}\end{array}$ & (a) $1.17-1.30(\mathrm{~m}, 9 \mathrm{H})$, (b) $3.27-3.37(\mathrm{~m}, 4 \mathrm{H})$, (c) $3.57(\mathrm{~m}, 1 \mathrm{H}),(\mathrm{e}) 7.24-7.29(\mathrm{~m}, 8 \mathrm{H}),(\mathrm{f}) 9.22$ (br.s, $\mathrm{IH})$ \\
\hline
\end{tabular}

* In DMSO-d 6<smiles>CCN(CC)C(C)CN1c2ccccc2Sc2ccccc21</smiles>

Figure 2. Molecular structure of the EP.HCl ligand showing different types of protons

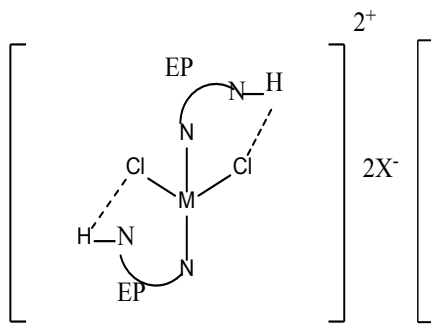

a.

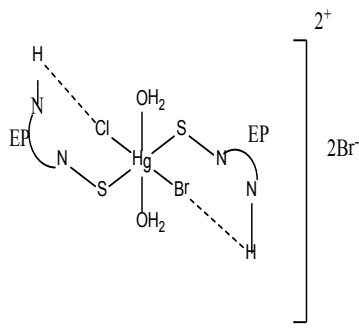

b.
Figure 3. a. Proposed general structure for the $\left[\mathrm{M}(\mathrm{EP} . \mathrm{HCl})_{2}\right]^{2+}$ complex ions, where $\mathrm{M}=\mathrm{Zn}(\mathrm{II})$ and $\mathrm{Cd}(\mathrm{II}) ; \mathrm{X}=\mathrm{Br}^{-}$or $\mathrm{I}$; $\mathrm{b}$. Proposed structure for the $\left[\mathrm{Hg}(\mathrm{EPHCl})(\mathrm{EPHBr})\left(\mathrm{OH}_{2}\right)_{2}\right]^{2+}$ complex ion

\section{Conclusions}

Transition metal(II)- ethopropazine hydrochloride complexes ethopropazine hydrochloride have been prepared and characterized using such analytical data as elemental analysis, molar conductance, magnetic susceptibility, IR and $\mathrm{H}^{1}$-NMR. The molecular structures of the metal complexes have been presented. The future plan of work includes the determination of free radical and antioxidant activities using standard assays.

\section{ACKNOWLEDGEMENTS}

The authors are grateful to the Western Illinois University Research Council, Graduate Student Research and Professional Development Fund, and the National Cancer Institute-NIH (AREA grant \# 1R15 CA115404-01) for support.

\section{REFERENCES}

[1] Snyder, S.H., 1976, Amer. J. Psychiatry, 133, 197

[2] O. Bratfos and J.O. Haug, Acta Psychiat, Scand., 60, 1, 1979

[3] A.R. Katritzky and A.J. Boulton (Eds.), Advances in heterocyclic Chemistry, Academic press, New York, 1968

[4] Keshavan, B., and Seetharamappa, J., 1987, Polyhedron, 6(3), 465

[5] Keshavan, B., and Seetharamappa, J., 1986, Synth. React. Met.-Org. Chem., 16(7), 979

[6] Keshavan, B., and Janardhan, R., 1987, Ind. J. Chem., 26A, 975

[7] Keshavan, B., and Janardhan, R., 1987, Ind. J. Chem., 25A, 1054

[8] Sanke Gowda, H., and Jayarama., 1981, J. Inorg. Nucl. Chem., 43(10), 2329

[9] Kroener, R., Heeg, M. J., and Deutsch, E., 1988, Inorg. Chem., 27, 558

[10] Made Gowda, N.M., and Phyu, H.P., 1992, Ttransition Met. Chem., 17, 467; H.P. Phyu, M.S. Thesis, Western Illinois University, Macomb, USA, May, 1991

[11] Made Gowda, N.M., Phyu, H.P., and Ackerson, B.E., 1993, Transition Met. Chem., 18, 64

[12] Made Gowda, N.M., Kyi, M.M., and Zhang, L., 1993, Transition Met.Chem., 18, 518; M.M. Kyi, MS. Thesis , Western Illinois University, Macomb, USA, December 1991; 
Made Gowda, N.M., and Zhang, L., 1994, Synth. React. Inorg. Met-Org. Chem., 24(5), 831; L. Zhang, M.S. Thesis, Western Illinois University, Macomb, USA, May, 1992

[13] Made Gowda, N.M., Ackerson, B.E., Morland, M., and Rangappa, K.S., 1993, Transition Met. Chem., 18, 271

[14] Made Gowda, N.M., Pacquette, H.L., Kim, D.H., and Jayaram, B., 1996, J. Mol. Struct., 382 ,129; Made Gowda, N.M., Vallabhaneni, R.K., Gajula, I., and AAFZAL, D., 1996, Synth. React. Inorg. Met-Org. Chem, 26(4), 685

[15] Made Gowda, N.M., Lawrence Pacquette, H., Kim Doo-Hyung, Jayaram, Beby, 1996, J. Mol. Struct, 382, 129-135; Made Gowda, N.M., Rouch, W.D., and Viet, A.Q., 1993, The Chemistry of copper and Zinc Triads., Royal Society of Chemistry, Cambridge, U.K, 117-120

[16] Made Gowda, N.M., Vallabhaneni, R.K., Gajula, I., Ananda, S., 1997, J. Mol. Struct., 407, 125-130

[17] Chaitanya Lakshmi G., Ananda S., and Made Gowda N.M., 2011, Synthesis, characterization, and antioxidant activity evaluation of pyridoxine and its transition metal complexes., Synthesis and Reactivity in Inorganic, Metal-Organic and Nano-Metal Chemistry, 41, 1-12
[18] Chaitanya Lakshmi G., Ananda S., and Made Gowda N.M., 2009, Synthesis, Characterization and Antioxidant Activity of Zinc(II) and Ruthenium(III) Pyridoxine Complexes., Synthesis and Reactivity in Inorganic, Metal-Organic and Nano-Metal Chemistry, 39(8), 434-440

[19] Chaitanya Lakshmi G., Ananda S., and Made Gowda N.M., 2010, Synthesis of Iron-Pyridoxine Complex by Solvothermal Process, Its Structural Characterization and Antioxidant Activity Evaluation., J. Chem. Chemical. Engg, 4(12), 33-37

[20] J.M. Huheey, E.A. Keiter and R.L. Keiter, Inorganic Chemistry; Principles of Structures and Reactivity, 4th ed., Harper Collins College Publishers, 1993

[21] L.J. Bellemy, The Infrared Spectra of Complex Molecules, Methuen, London, p.355, 1964

[22] K. Nkamoto, Infrared Spectra of Inorganic and Coordination Compounds, Wiley Interscience, New York, 1970

[23] D.A. Skoog and D.M. West, Principles of Instrumental Analysis, Saunders College, P.A, 1980, 171-173

[24] Jayarama, Thimmaiah, K.N., and D'Souza, M.V., 1985, J. Indian Chem. Soc., 62, 418 